Article

\title{
Corporate Social Responsibility and Managerial Compensation: Further Evidence from Spanish Listed Companies
}

\author{
Fabián Blanes, Cristina De Fuentes and Rubén Porcuna *D \\ Accountancy Department, Faculty of Economics, University of Valencia, 46022 Valencia, Spain; \\ fablasa@alumni.uv.es (F.B.); dfuentes@uv.es (C.D.F.) \\ * Correspondence: ruben.porcuna@uv.es; Tel.: +34-963828298
}

Citation: Blanes, F.; De Fuentes, C.

Porcuna, R. Corporate Social

Responsibility and Managerial Compensation: Further Evidence from Spanish Listed Companies. Sustainability 2021, 13, 7341. https: //doi.org/10.3390/su13137341

Academic Editor: Donato Morea

Received: 31 May 2021

Accepted: 25 June 2021

Published: 30 June 2021

Publisher's Note: MDPI stays neutral with regard to jurisdictional claims in published maps and institutional affiliations.

Copyright: (c) 2021 by the authors. Licensee MDPI, Basel, Switzerland. This article is an open access article distributed under the terms and conditions of the Creative Commons Attribution (CC BY) license (https:// creativecommons.org/licenses/by/ $4.0 /)$.

\begin{abstract}
Ongoing regulatory efforts aim to link managerial compensation with a firm's performance. However, little is known about whether and how Corporate Social Responsibility (CSR) goals are considered in the design of the managerial compensation scheme. This paper addresses this research question by analyzing a sample of Spanish listed firms for the period spanning 2013-2018. The outcomes of the regressions suggest that there is a positive relationship between CSR and the managerial compensation, but this relationship is significant only with lower levels of CSR. The study also reveals that CSR is positively associated with the proportion of equity-based compensation and, therefore, negatively associated with the proportion of cash-based compensation. In all, our results suggest that firms with lower levels of CSR, likely following social pressures, seek to improve their investments in CSR; and, in doing so, they design a managerial compensation scheme that incentivizes the manager to meet the firm's goals related to CSR investments. Hence, since CSR is associated with an increase in the long-term firm's value, the equity-based component of the managerial scheme is higher than in the remaining firms. However, the high proportion of cashbased compensation is far from the desirable goals promoted by the Governance Codes.
\end{abstract}

Keywords: managerial compensation; corporate social responsibility; CEO compensation; executive compensation; compensation structure

\section{Introduction}

This study aims to explore whether and how CSR goals and managerial compensation schemes are connected. In the last decades, executive compensation has drawn great attention from academia, the public, media and institutions. The critics rocketed during the 2008 financial crisis because it seemed that, in some cases, the executives had been excessively rewarded in spite of the firms facing severe financial distress [1,2]. Moreover, stockholders were also dissatisfied with the managerial compensation policies, because $90 \%$ of institutional investors believed that corporate executives were overpaid [3]. From the social perspective, the evolution of the managerial emoluments has also been criticized: In the world's 350 biggest companies, the gap between the CEO's pay and that of the average worker widened from 20:1 in 1965 to 278:1 in 2018 [4].

In response to the public debate, the regulatory bodies have released a bundle of documents on good governance: According to Cuomo et al. [5], since 1992 more than 354 Governance Codes had been released, with a peak in publications in 2009 and 2010, after the global financial crisis. Those Corporate Governance (CG) codes include recommendations on the executive compensation's schemes (such as OECD Principles of Corporate Governance, 2015 [6]; Recommendation 2009/385/CE [7]). These measures are primarily rooted in the agency theory [8,9]. Within this framework, one of the instruments to mitigate the agency costs is through designing a manager's optimal contract [10-12] that requires the executive compensation scheme to be tied to the firm's short- and long-term performance in order to closely align the agent (managers) and the principal (shareholders) interests. 
At the same time, undoubtedly, there is an increasing awareness of the relevance of Corporate Social Responsibility (CSR) issues at the international level: good examples of the regulatory efforts around the world are the Duty of Vigilance Law in France, 2017 [13], the UK 2006 Companies Act [14], China's Company Act 2006 [15], or India's Company Act, 2013 [16].

Hence, following this trend and social pressure, many companies have included CSR elements in the executive compensation scheme: $43 \%$ of the Fortune 500 firms include CSR as part of the managerial compensation, according to the joint report by the Investor Responsibility Research Center and the Sustainable Investments Institute (2013) [17].

Nevertheless, the reasons why and how firms develop and implement CSR policies are difficult to investigate due to the limited access to the firms' strategic internal information, and therefore most of the CSR research is based on the firms' disclosures in financial and non-financial statements. The link between CSR investments and managerial compensation does not constitute an exception. The extant literature that explores the relationship between $\mathrm{CEO}$ compensation and firm performance is prolific, i.e., the meta-analysis by Tosi et al. [18] and Blanes et al. [19] is nourished by 104 publications that explore the pay-performance association. However, there is still scarce empirical evidence about the association between managerial compensation and CSR performance, and the conclusions, mostly based on archival data, are inconclusive. Thus, it remains an empirical issue that deserves further attention.

Our study aims to cover this gap and explores the link between CEO/Executive compensation and CSR. The extant published investigations on a single country are disproportionately concentrated in the UK and the USA [20-25]. However, those findings can hardly apply to alternate settings: In the Anglo-Saxon countries, under the common-law legal system, investors are strongly protected, the stock markets are well developed, and public companies are owned by a large number of shareholders [26]. In those countries, such as the US, the UK, Canada, or Australia, the traditional manager-shareholder agency conflict arises, and monitoring managers is the main role of the board of directors. However, in non-Anglo-Saxon countries, investors have lower institutional protection [27], stock markets are less developed than those of the Anglo-Saxon countries [28], and firm ownership is highly concentrated [29]. In this scenario, the conflict of interest between majority and minority shareholders is the most prevalent agency problem (also known as the principal-principal agency cost), and the majority shareholders either participate in the company's management or they invest time and resources in supervising the managers, since they are facing high investment risks [30].

To shed some light over governance mechanisms developed in environments other than the Anglo-Saxon ones, this investigation provides insights from companies settled in Spain, a common law country [26] that represents an interesting setting to investigate for several reasons: (i) the ownership structure of listed Spanish companies, contrary to their Anglo-Saxon counterparts, is highly concentrated in the hands of institutional investors such as banks, insurance companies, or investing funds, with a high proportion of directors representing institutional investors [31,32] who have proved influential in the design of the managerial compensation structure [33]; (ii) the issuance of hard (Sustainability Act, 2011 [34]; Companies Act, 2014 [35]; Non-financial information Act 11/2018 [36]) and soft (New Code of Good Governance, 2015 [37]) laws have promoted new managerial compensation schemes, but requires non-financial and CSR information disclosures. Therefore, there are novel sources of information that could help to further understand whether and how the design of the managerial compensation and CSR disclosures are connected.

This study explores the association between CSR disclosures and managerial compensation schemes. We build on the CSR definition by Jo and Harjoto [38], that includes three dimensions of CSR - environmental, social, and governance (ESG) aspects-that, at the same time, are used to assess CSR performance. Following Jian and Lee [24] and Karim, Lee, and Shu [23], we explore the association between managerial compensation and different levels of CSR. Finally, we aim to expand the contribution by Lopez-Iturriaga 
et al. [33], which revealed how the institutional board members influence the managerial compensation scheme in Spain by considering the influence of CSR investments in the design of the compensation structures.

To achieve that goal, from a multitheoretical perspective, we analyze the link between CEO/Executive compensation and CSR in a sample of Spanish listed companies that disclose both managerial compensation and CSR data. The period of analysis starts in 2013 (the first year in which compensation data were available in Spain, as required by the Companies Act, 2014 [35]) and ends in 2018. Following the previous pay-performance literature [39-41], we control for corporate governance variables and company characteristics.

The study reveals that $\mathrm{CEO}$ and Executive (total and variable) compensations are positively associated with CSR performance. This relationship is positive only for the groups of firms with lower CSR investments because the we failed to prove any significant association between our variable of interest and upper (abnormal) CSR levels. Regarding the managerial compensation structure, CSR is positively associated with equity-based compensation and negatively linked to cash-based compensation.

This investigation should be extended by contributions carried out in other countries with different governance characteristics, as those spotted by Claessens et al. [29] or Kim et al. [42], so that we can have deeper knowledge of the effective design of managerial compensation in alternate settings.

The paper shows the following structure: Section 2 reviews the prior evidence and places the hypotheses on the theoretical framework; Section 3 sets the sample of the study and the methodology applied; Section 4 explains the results obtained from the analyses performed in order to answer the hypotheses; finally, Section 5 concludes the study.

\section{Theoretical Background and Hypothesis Development}

The design of the managerial compensation scheme has largely been the focus of the academics and regulators debate. Several theories attempt to formulate the optimal compensation contract (from a normative point of view) and/or explain the research findings (from a positive research perspective). Following these attempts, we disclose the main arguments posited by the scholars and the main empirical results.

Two theories lie behind the two main drivers of CEO pay, i.e., firm performance and firm size. Under the market-based agency theory $[8,9]$ the manager (agent) seeks to maximize his/her own benefit despite the shareholder's (principal) interest. In seeking their own interest, managers do not always adopt decisions that increase the firm's value. Among the solutions to mitigate this agency conflict, agency theorists postulate that the design of the managerial compensation is an effective tool [43]. Moreover, the optimal contracting of the agency framework predicts that the pay-performance rewarding scheme provides the best alignment between the CEO and the shareholder's interests [44-46].

In the European Union, regulatory bodies and standard setters (e.g., FRC, 2010 [47]; EU Directive 2013/36/E [7]) have followed the agency premises and seek to strengthen the link between the CEO compensation and the firm's short/long performance. Moreover, they aim to constrain the discretion in CEO pay and to implement equity-based components in the compensation policies. They also promote: (i) the empowerment of shareholders to monitor the compensation policy's compliance (say-on-pay clause) and (ii) the remuneration committee, consisting exclusively of non-executive or supervisory directors.

However, the empirical evidence has consistently proved the predominance of the pay-size correlation over alternative performance variables (see the meta-results by Tosi et al. [18] or Blanes et al. [19]).

Why is firm size the main driver of managerial compensation when the firm's performance best aligns the interests of managers and shareholders, as the ongoing good governance recommendations state? Among the attempts to explain the empirical findings, the managerial power theory [40] posits that, when managers are powerful, the managerial compensation constitutes the problem rather than the solution to the agency cost: When the managers are powerful, they exert their influence on the remuneration committee and 
on the board, and so the design of the compensation scheme maximizes their self-interests. Therefore, they will try to increase the relative weight of the firm's size and decrease the relative weight of the firm's performance in the total compensation scheme. The reason is that they have more control through new investments or acquisitions (in spite of any damage in profits) and that bigger companies may also lead to more power and prestige [40,48,49].

In addition, the global increasing awareness of CSR issues has triggered new regulations (Directive 2014/95/UE [7]; Law 11/2018 [33] for non-financial information; Law 9/2020 [50] that modifies the Law 2005 about carbon emissions) and external pressures for the firms to address environmental, gender, or sustainable targets, among others. However, the stakeholders' concerns about CSR and the effort of firms to reach these external expectations could be a double-edged sword as long as these CSR strategies are done with the objective of faking a good image instead of directing this CSR investment toward the global benefit, that is, stakeholders' profits [51,52].

Following these conclusions, we disclose how the mainstream theories integrate CSR investments and the managerial compensation and formulate the research hypotheses.

\subsection{Direct Association between CSR Performance and CEO/Executive Compensation}

Among the well-established theories on the CSR field, the stakeholder theory [53,54] states that the management of modern firms must be oriented to satisfy not only the shareholders but also all stakeholders' interests, and, to achieve this goal, firms develop a network of contracts between shareholders and stakeholders (employees, public administrations, suppliers, and society, among others). Under this framework, managers focus on exercising responsible contracts in every domain of the social responsibility of the firm in order to be more transparent and bring the stakeholder perception closer $[37,48,55]$. In this context, CSR investments will be associated with a higher attraction of qualified employees [54], an easier access to high-quality products and suppliers [56], and customers' fidelity [57]. If higher CSR investments satisfy the interest of other stakeholders, they will be more likely to support the firm's operation in return, which will increase shareholders' value and, ultimately, the managerial compensation.

The meta-results provided by [58] demonstrate that CSR investments had a positive impact on the corporate financial performance, with this link being stronger in the UK context. Regarding the sign of the association between the CSR investments and managerial compensation, as posited by [24], higher CSR investments will trigger a positive impact on the firm value, increasing managerial compensation as a result of the financial performance growth.

However, the positive impact of CSR investments on the firm's financial performance (and, eventually, on the managerial compensation) predicted by the stakeholder theory has not always been corroborated by the archival research. Empirical evidence on the indirect impact of CSR investments on the managerial compensation is not conclusive because some important gaps in the value transmission chain have been identified. Several alternate theoretical frameworks predict and/or explain the final indirect negative association between the firm's CSR policies and the managerial compensation.

For instance, according to the agency premises, the outcome of the managerial decisions related to CSR is not clear: If the manager considers that CSR is part of the expenses rather than the investments and, therefore, reduces the company's profits, the manager will try to minimize CSR, since it lessens both the shareholders' return and the CEOs/executives' compensation $[59,60]$. This is also consistent with the argument of a higher transparency and investment in CSR when a firm's financial situation is healthy, and lower efforts when it is in crisis [61].

In all, the indirect relationship between CEO and executive compensation and CSR through the firm's value is not clear, and the literature offers miscellaneous results.

Alternate research attempts have explored the direct link between CSR and managerial compensation. The conflict-resolution hypothesis predicts that socially responsible firms prefer to pay a low CEO compensation to reduce potential conflicts of interests among stakeholders [22,37]. In this vein, Potts [62] argued that firms with high CSR performance 
may decrease their CEO compensation because a high salary is not what is expected of a socially responsible company. According to these postulates, Cai, Jo, and Pan [22] concluded that a greater reduction of the CEO compensation is preferable in socially responsible companies.

Some archival investigations support this negative association: Jian and Lee [24], by using a sample with 1680 firms for the 1992-2011 period, found that CEO compensation was negatively associated with CSR investments. Cai et al. [22] showed that an interquartile increase in Corporate Social investment resulted in a $4.35 \%$ decrease of CEO Total Compensation. Russo and Harrison [63] found an inverse relationship between CEO compensation and environmental reputation, using a sample of 186 US firms.

However, if the company is trying to imitate other socially responsible firms, according to the institutional isomorphism developed by DiMaggio and Powell [64] and corroborated by, among others, Mizruchi and Fein [65] or Fernando and Lawrence [66], it will try to hire managers with a high reputation in this field. Hence, the managerial compensation might increase with CSR parameters. This relationship was corroborated in Milbourn [67] because he found a positive relation between CEO stock-based compensation and CSR reputation. McGuire et al. [21] revealed that both CEO salaries and long-term compensation were positively related to CSR performance. Berrone and Gomez-Mejía [68] showed that in contaminating sectors, firms that improved their environmental performance increased CEO compensation. Karim, Lee, and Suh [23] found that the social performance of companies enhanced the quality of the managerial packages because the equity-based compensation increased and the cash-based retribution decreased.

Therefore, the direct association between the firm's CSR investments and the managerial and executive compensation still remains an empirical issue. Thus, considering alternate theories and contradictory empirical findings, we test the research hypothesis that adopts the following terms:

Hypothesis 1 (H1). CSR performance is negatively or positively associated with CEO/Executive compensation.

\subsection{Direct Association between CSR Performance and CEO/Executive Compensation}

To further explore the relationship between CSR and managerial compensation, following Jian and Lee [24], we analyze whether managerial compensation exhibits different relationships with CSR according to the levels of CSR investments.

The vast majority of investors consider the CSR information as part of their investment strategies, especially when CSR affects companies' performance and enhances the transparency and the integral reporting systems [51,69]. Therefore, managers and firms are incentivized to invest in CSR.

Nevertheless, under the mimetic isomorphism described by DiMaggio and Powell [64], managers would invest on CSR trying to imitate other firms in the same industry or well-reputed managers. In this vein, Surruca and Tribó [70] show that, often, managers' CSR investment is focused on increasing the ceremonial protocols that enhance their networks and social prestige, because CSR investment faces larger effects than other mechanisms [51,52]. Moreover, Barnea and Rubin [71] argue that, in pursuing their own reputation enhancement, CEOs tend to overinvest in CSR, among other reasons because they perceive the pressure from the stakeholders and institutions [72]. Therefore, there is a casual negative relationship between CSR, a firm's value and, eventually, the managerial compensation.

In this vein, Jian and Lee [24] demonstrate that, for firms with good governance mechanisms, CEO compensation is positively (or negatively) associated with normal (or abnormal) CSR investments. Therefore, CEOs receive a lower compensation for excessive CSR investments.

According to the isomorphist behavior postulated by the institutional theory and prior empirical results, we conjecture that higher CSR investments (i.e., overinvestments in 
CSR) are associated to lower managerial compensations. Hence, to test this prediction we formulate the following hypotheses:

Hypothesis 2a (H2a). Lower CSR performance is positively associated with CEO/Executive compensation.

Hypothesis $\mathbf{2 b} \mathbf{b} \mathbf{H} \mathbf{2 b})$. Higher CSR performance is negatively associated with CEO/Executive compensation.

\subsection{Direct Association between CSR Performance and the CEO/Executive Compensation Components}

The compensation packages exhibit a wide variety [73], though traditionally it includes compensation in the form of cash (e.g., salary and bonus) and components that include long-term contingent payments (e.g., stock options and other long-term incentive plans). Meanwhile, managers prefer cash-payments because they are associated to short-term targets and consist of a high fix component (salary); the Governance Codes, under the agency premises, promote long-term considerations (that may include the pay back, such as the clawback clause), because long-term compensation aligns the interests of executives and shareholders [73].

Following this reasoning, if CSR investments are expected to increase a firm's value, then the proportion of shares and long-term-based managerial compensation should be high. On the contrary, if the CSR investments are just a symbolic makeup that does not really intend to improve the firm's social performance, and managers are seeking instead their own (short-term) benefits (i.e., through a higher social reputation), those expenses might ultimately (in the long term) negatively impact on the firm's value. Then, the managers would prefer a higher proportion of the short-term-based compensation (salary and other cash-based components) than the long-term based compensation. Empirical evidence has corroborated this premise [23,74]. However, the contrary reasoning also applies, because Peng [73] reveals that if a manager is convinced of the long-term benefits that CSR investments will trigger, as a prospector strategy, he/she will more likely accept long-compensation components in the managerial package in spite of the proportion of the short-term-based compensation proportion [75].

In addition, some researches revealed that the positive link is displayed for both components, salary and long-term compensation [21], and stricter settings that contribute to investors protection and law compliance also trigger a higher effect of the manager pay slice on CSR efforts [76].

In all, prior research offers miscellaneous results about the association and causality between managerial compensation components and CSR investment [77]. Therefore, following prior contradictory evidence, we will test the following hypotheses:

Hypothesis 3a (H3a). CSR performance is positively or negatively associated with the proportion of CEOs' cash-based compensation.

Hypothesis $\mathbf{3 b} \mathbf{b} \mathbf{H} \mathbf{3 b})$. CSR performance is positively or negatively associated with the proportion of CEOs' equity-based compensation.

\section{Sample of the Study and Methodology}

\subsection{Sample}

The initial sample (displayed in Table 1) consists of 167 companies (1002 firm-year observation) listed in the Madrid Stock Exchange at any moment during the period of study (2013-2018). However, the final sample is lower due to the following reasons: (i) 55 companies (330 firm-year observations) do not have a CEO inside the Board of Directors and, therefore, we lack information regarding the CEO compensation scheme; (ii) 
some companies are unlisted during the period of study (372 and 97 firm-year observations for the CEO and Executive sample, respectively); and (iii) the Eikon database (source of this study) does not include the CSR information about some firms (334 and 330 firmyear observations for the CEO and Executive sample, respectively). Hence, the final sample consists of 296 firm-year observations for the Executive compensation sample and 246 firm-year observations for the CEO compensation sample, similarly to samples used in prior research [78-80]. For the statistical purposes, both panel data are strongly balanced.

Table 1. Sample selection.

\begin{tabular}{ccc}
\hline & $\begin{array}{c}\text { Executive Compensation } \\
\text { Sample }\end{array}$ & $\begin{array}{c}\text { CEO Compensation } \\
\text { Sample }\end{array}$ \\
\hline $\begin{array}{c}\text { Initial sample } \\
\text { Undisclosed information on }\end{array}$ & 1002 & 1002 \\
compensation because CEO is not & & $(330)$ \\
part of the board & & $(97)$ \\
Unlisted during the period of study & $(372)$ & 576 \\
Sample (firm-year observations) & 630 & $(330)$ \\
CSR information non-reported in & $(334)$ & 246 \\
EIKON Database & 296 & \\
Final Sample & &
\end{tabular}

The industry classification of the sample according to CNAE criteria is displayed in Table 2. It is observable that the most representative industries in our sample are: Manufacturing, Business Services, and Communication, which contains 20, 11, and 7 companies, respectively. They are followed by the rest of the industries, whose percentage for every one is under $10 \%$.

Table 2. Sample classification according to industry criteria.

\begin{tabular}{cccc}
\hline CNAE ID & Industry & Firms & \% \\
\hline 1 & Business Services & 11 & 16.92 \\
2 & Communications & 7 & 10.77 \\
3 & Construction & 5 & 7.69 \\
4 & Manufacturing & 20 & 30.77 \\
5 & Mining \& Extraction & 2 & 3.08 \\
6 & Real Estate Services & 6 & 9.23 \\
7 & Education \& Health & 2 & 3.08 \\
8 & Travel, Leisure \& & 5 & 7.69 \\
9 & Tourism & 5 & 7.69 \\
10 & Utilities & 2 & 3.08 \\
\hline
\end{tabular}

\subsection{Model Specification}

In order to test the formulated hypotheses, we use panel data (following [81]) because the results of the models are generally more robust, since they consider full information from all observations across cases and over time in the same dataset. In addition, all our regressions are robust to overcome some limits of the parametric and non-parametric regressions and improve the consistency of our estimators. We build on the models proposed by Cai et al. [22] and Jian and Lee [24] and estimate the following regressions of CEO/Executive compensation on CSR scores:

CEO/Executive_compensation $i, t=\beta_{1}$ ESGCScore $_{i t}+\beta_{2} \mathrm{ROE}_{i, t}+\beta_{3}$

Sales $_{i, t}+\beta_{4}$ Leverage $_{i, t}+\beta_{5}$ BoardSize $_{i, t}+\beta_{6}$ BoardAct $_{i, t}+\beta_{7}$ BoardIndep $_{i, t}$

$+\beta_{8}$ OwnerCon $_{i, t}+\beta_{9}$ BoardOwn $_{i, t}+\beta_{10}$ Ceodual $_{i, t}+$ industry $_{i, t}+$ year $+\varepsilon_{i, t}$ 
where the dependent variable is either $\mathrm{CEO}$ or executive compensation. For the purpose of our study we will analyze the variable, total, cash-based, and equity-based components of the compensation (as in $[23,33]$ ). The definition and measurements of the variables are provided in Appendix A.

\subsection{Variable of Interest}

To measure CSR performance we use a multidimensional index, i.e., the Thomson Reuters Eikon ESG (Environmental, Social, and Governance) scores for each individual firm, as in Pucheta-Martinez and Gallego-Alvarez [82]. The ESG score is an index specifically designed to measure the performance of each firm in 10 different ESG categories (displayed in Table 3) and considering 178 items, according to the company disclosure. This variable ranges between 0 and 1 . Accordingly, a firm with 0 points discloses no CSR information, a firm with $0.1-0.5$ points makes a moderate disclosure of CSR information, a firm with 0.6-0.9 points makes a relevant disclosure of CSR information, and a firm with 1 point makes a complete disclosure of CSR information.

Table 3. Indicators of ESG score.

\begin{tabular}{|c|c|c|c|}
\hline Pillar & Category & Indicators in Scoring & Weights \\
\hline \multirow{3}{*}{ Environmental } & Resource Use & 20 & $11 \%$ \\
\hline & Emissions & 22 & $12 \%$ \\
\hline & Innovation & 19 & $11 \%$ \\
\hline \multirow{4}{*}{ Social } & Workforce & 29 & $16 \%$ \\
\hline & Human Rights & 8 & $4.50 \%$ \\
\hline & Community & 14 & $8 \%$ \\
\hline & $\begin{array}{c}\text { Product } \\
\text { Responsibility }\end{array}$ & 12 & $7 \%$ \\
\hline \multirow{3}{*}{ Governance } & Management & 34 & $19 \%$ \\
\hline & Shareholders & 12 & $7 \%$ \\
\hline & CSR Strategy & 8 & $4.50 \%$ \\
\hline \multicolumn{2}{|c|}{ TOTAL } & 178 & $100 \%$ \\
\hline
\end{tabular}

Source: Thomson Routers Eikon Database.

In our analysis, we use the overall ESG Combined score (labeled ESGCScore), which is calculated discounting from the ESG score the impact of bad news controversies which materially impact the companies, that is, the calculation is as follows:

ESG combined score $=$ ESG score - ESG controversies score

\subsection{Control Variables}

The model controls for several factors: the $\mathrm{CEO}$ and the executive remuneration are highly determined by the firm's size, as the metaresults by Tosi et al. [18] or Blanes et al. [19] corroborate. Typically ([83-85] among others), this construct is operationalized through the Sales variable. In order to reduce its variability, it adopts the natural logarithm form.

In operationalizing the construct Performance, following Bertrand and Mullaintathan [86], we employ the profitability ratio Return on Equity (ROE), widely used in prior literature [87-89], that shows the manager's ability to turn shareholder investments into profits.

A high firm's Leverage is expected to control and influence managerial compensation, because financial borrowers act as external or internal monitoring agents [90], in order to reduce the risk exposition of the financial entity. The ratio is measured through total 
debt/total assets, which include both the current and long-term liabilities, as in Basu et al. [91] and Chung et al. [92]

The model also comprises the following governance variables: Board of Directors' size (BoardSize), that is, the total members of the Board of Directors [93-95]; the number of board meetings per year, labeled BoardAct [96-98]; the number of independent members in the board (BoardIndep), following Pucheta and Gallego [82]; the ownership concentration (OwnerCon) that measures the presence of blockholders [99]; the dummy variable CEOdual [92,100], that identifies when the CEO is the same person that chairs the board of directors; and the Board Ownership (BoardOwn), that measures the percentage of shares controlled by the board [41,101]. Finally, the model controls for industry and year-fixed effects.

\section{Empirical Results}

\subsection{Descriptive Statistics}

The descriptive statistics related to the CEO and Executive compensation and the remaining variables of the model for the period spanning 2013 to 2018 are displayed in Table 4.

Table 4. Descriptive statistics.

\begin{tabular}{|c|c|c|c|c|c|}
\hline \multicolumn{6}{|c|}{ Panel A. CEO Compensation. 54 Companies. Data in Thousand Euros } \\
\hline Variable & Obs & Mean & Std.Dev. & Min & Max \\
\hline Total_Var & 246 & 1488 & 1756 & 10 & 12,842 \\
\hline Total_Pay & 246 & 2642 & 2656 & 164 & 19,505 \\
\hline P_Equity $(\%)$ & 246 & 3.98 & 13.36 & 0 & 96.48 \\
\hline P_Cash $(\%)$ & 246 & 96.02 & 13.36 & 3.52 & 100 \\
\hline \multicolumn{6}{|c|}{ Panel B. Executive Compensation 65 Companies. Data in Thousand Euros } \\
\hline Variable & Obs & Mean & Std.Dev. & Min & Max \\
\hline Total_Var & 296 & 1477 & 1950 & 5 & 12,842 \\
\hline Total_Pay & 296 & 2403 & 2351 & 75 & 13,205 \\
\hline P_Equity $(\%)$ & 296 & 9.81 & 19.61 & 0 & 92.64 \\
\hline P_Cash (\%) & 296 & 90.19 & 24.11 & 7.37 & 100 \\
\hline \multicolumn{6}{|c|}{ Panel C. Financial Variables. } \\
\hline Variable & Obs & Mean & Std.Dev. & Min & Max \\
\hline Sales & 296 & $8,480,000$ & $1,280,00$ & 360 & $57,600,000$ \\
\hline Leverage & 296 & 0.66 & 0.26 & 0.05 & 2.11 \\
\hline ROE & 296 & 13.76 & 40.27 & -313.39 & 173 \\
\hline \multicolumn{6}{|c|}{ Panel D. RSC and Governance Characteristics Variables } \\
\hline Variable & Obs & Mean & Std.Dev. & Min & Max \\
\hline ESGCScore & 296 & 59 & 21 & 0.63 & 91.74 \\
\hline BoardOwn & 242 & 12 & 18 & 0 & 66.90 \\
\hline OwnerConc & 244 & 34 & 22 & 0 & 94 \\
\hline BoardSize & 243 & 12.44 & 3 & 5 & 20 \\
\hline BoardIndep & 243 & 76 & 12 & 40 & 100 \\
\hline BoardAct & 243 & 10.65 & 4 & 4 & 42 \\
\hline CEOdual & 254 & 0.69 & 0.48 & 0 & 1 \\
\hline
\end{tabular}

Of note, the sample includes the biggest listed firms, i.e., those included in the IBEX35 index and mid-caps, because they are the ones that disclose the RSC information and are compiled in the ESGCScore.

Data related to CEO compensation are displayed in Table 4, Panel A. On average, the variable pay is 1488 thousand euros. Regarding the Executive compensation data (Table 4, Panel B), the mean of variable pay and total pay is 1477 and 2403 thousand euros, respectively, that is, they are lower than the CEO counterpart. This is because the CEO has the highest executive management functions, while the executive compensation is 
an average of all executive managers, including those with a lower rank than the CEO. Remarkably, the minimum values of Executive compensation (75,000 euros) correspond to years where companies (i.e., Solaria or DIA) were facing financial distress, while the CEOs at the IBEX35 companies (Inditex, Iberdrola, Telefónica, and OHL) received the highest compensations.

Moreover, regarding the compensation structure ( $P_{-}$Equity and $P_{-}$Cash), the mean of cash-based proportion in compensation is significantly higher than the equity-based compensation, both for CEO (96.01\%) and Executive $(90.91 \%)$. However, there are companies (e.g., Masmovil and Talgo) that mainly pay with shares, so they display the highest proportion of equity-based compensation for CEOs and Executives, that is, $96.48 \%$ and $92.64 \%$, respectively.

The Sales variable exhibits a wide range and high standard deviation. The lowest ROE values (-313.39) correspond to companies in the construction sector and to companies in the solar energy industry affected by changes in tax legislation.

Finally, Panel D in Table 4 shows the data related to the RSC index and CG variables. During the period of study, some firms were unlisted and did not release the Corporate Governance Annual Report. Hence, the number of CG observations is lower than the compensation and financial ones. On average, the board owns (BoardOwn) $12 \%$ of the shares and the significant shareholders (denoted by OwnerConc) hold 34\% of the equity. The average board size of the sample (12.44 members) lies within the recommended values disclosed in the Principle 10 of Governance Code 2015 (between 5 and 15). The percentage of independent members (BoardInd) is, on average, $76 \%$, above the minimum (50\%) recommended value (Recommendation 17 of the Governance Code 2015). The board holds, on average, 10-11 meetings per year, which also complies with the Recommendation 26 of the Governance Code 2015, that suggests a minimum of eight meetings per year. The CEO plays a dual role as chairman of the board in $69 \%$ of the observations. Regarding our variable of interest, the ESGCScore variable displays a mean value of 59, while Faes Farma exhibits the lowest ESGscore (0.63) and Inditex is the highest ranked firm (91.74).

\subsection{Correlation Analysis}

Table 5 displays the results of the Pearson correlation analysis of the variables of the model, both for the CEO and the Executive sample. In both samples (Panel A and Panel B), Total_Var and Total_Pay and the proportion of equity-based compensation (P_Equity) are positively correlated with Sales. ESGCScore also shows a significant positive correlation with, both, Total_Var and Total_Pay and proportion of equity-based compensation ( $\mathrm{P} \_$equity), but negative in the case of cash-based compensation ( $\mathrm{P} \_$Cash). In addition, there is a strong negative correlation between several compensation measures (Total_Var, Total_Pay and P_Equity) and OwnerConc. On the contrary, there is a positive and significant correlation between compensation measures (Total_Var, Total_Pay and P_Equity) and CEO Duality, but negative for P_Cash and CEO Duality, when we analyze the sample of CEO compensation (Panel A), and between Total_Pay and CEO Duality in the case of Executive sample (Panel B). Concerning multicollinearity, the post-regression analyses of the variance inflation factor (VIF) showed that the average VIF of the independent variables is under 10 in both panels from Table 5, suggesting that there are no multicollinearity problems [102,103]. 
Table 5. Pearson correlation matrix.

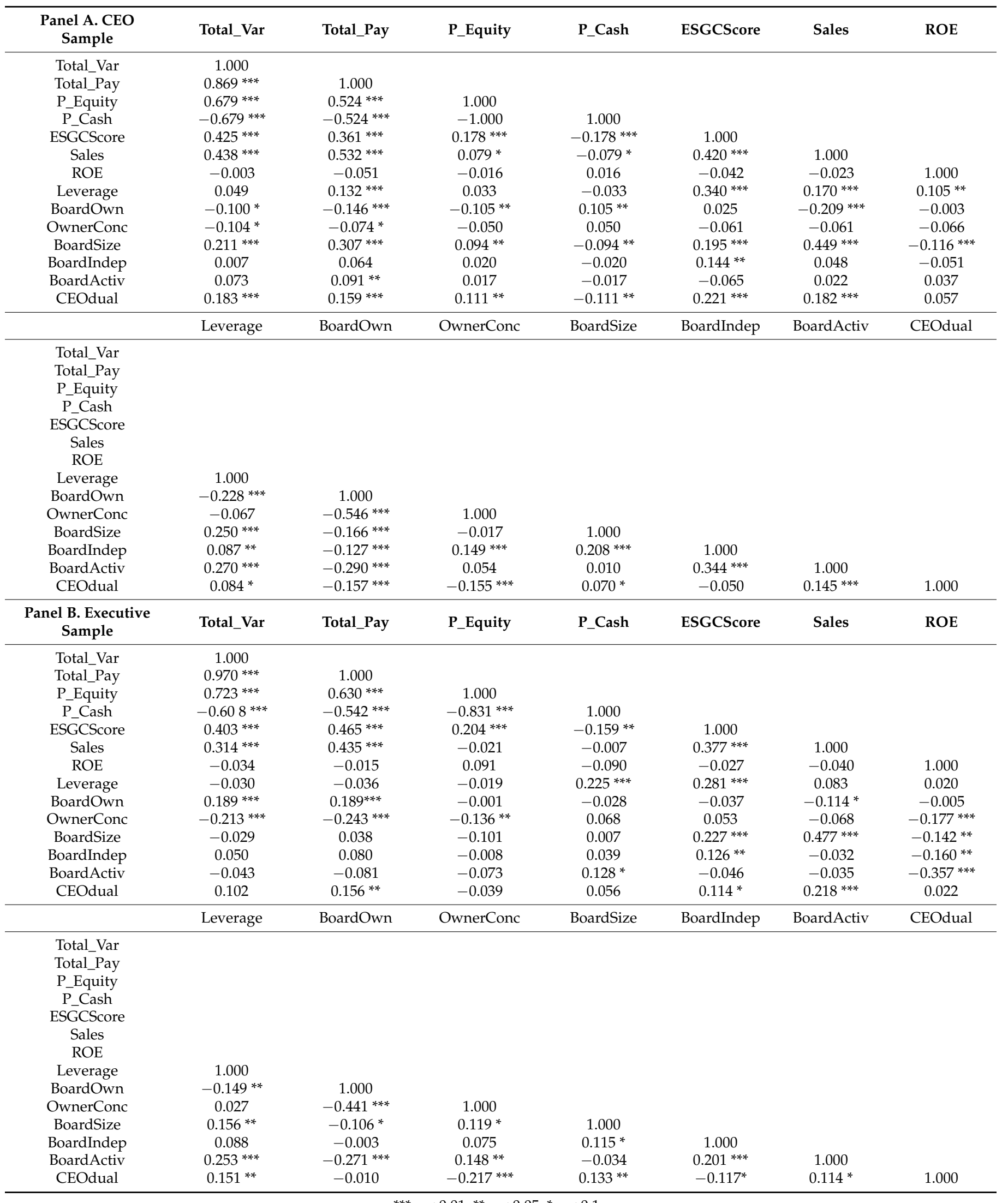




\subsection{Multivariate Analyses}

\subsubsection{Direct Association between CSR and CEO/Executive Compensation}

In Table 6 we display the results of model I using both CEO and Executive compensation and for both variable and total measures (H1). As we can observe, ESGCScore shows a positive and significant coefficient $(0.008)$ with both variable $\mathrm{CEO}$ and executive compensation, so, for each increment of 1 point in ESGScore, both CEO and Executive average variable remuneration increase by $0.8 \%$. Therefore, this finding suggests that there is a positive association between the firm's investment in CSR (measured through the ESGCScore) and the variable managerial compensation, thus confirming H1. The coefficients related with CEO and executive total compensations are lower (0.005 and 0.004, respectively) than the variable ones. In this case, each increment of 1 point in the ESGScore triggers an increase of $0.5 \%$ in the average CEOs' total compensation, and $0.4 \%$ in the average Executives' total remuneration. All coefficients but CEO Total Compensation show $99 \%$ of significance.

Table 6. CSR disclosure and CEO/Executive compensation.

\begin{tabular}{|c|c|c|c|c|}
\hline & $\begin{array}{l}\text { CEO Variable } \\
\text { Compensation }\end{array}$ & CEO Total Compensation & $\begin{array}{l}\text { Executive Variable } \\
\text { Compensation }\end{array}$ & $\begin{array}{l}\text { Executive Total } \\
\text { Compensation }\end{array}$ \\
\hline Variables & (1) & (2) & (3) & (4) \\
\hline \multirow[t]{2}{*}{ ESGCScore } & $0.008^{* * *}$ & $0.005^{*}$ & $0.008^{* * *}$ & $0.004^{* * *}$ \\
\hline & $(0.003)$ & $(0.002)$ & $(0.003)$ & $(0.002)$ \\
\hline \multirow[t]{2}{*}{ Sales } & $0.343^{* * *}$ & $0.309^{* * *}$ & $0.272 * * *$ & $0.251^{* * *}$ \\
\hline & $(0.077)$ & $(0.049)$ & $(0.079)$ & $(0.049)$ \\
\hline \multirow[t]{2}{*}{$\mathrm{ROE}$} & 0.000 & -0.000 & -0.000 & -0.000 \\
\hline & $(0.002)$ & $(0.001)$ & $(0.002)$ & $(0.001)$ \\
\hline \multirow[t]{2}{*}{ Leverage } & -0.481 & -0.286 & $-0.676^{* *}$ & $-0.327^{* *}$ \\
\hline & $(0.297)$ & $(0.208)$ & $(0.285)$ & $(0.155)$ \\
\hline \multirow[t]{2}{*}{ BoardOwn } & -0.005 & -0.002 & -0.000 & -0.000 \\
\hline & (0.004) & $(0.002)$ & $(0.004)$ & $(0.003)$ \\
\hline \multirow[t]{2}{*}{ OwnerConc } & $-0.011^{* * *}$ & $-0.005^{* * *}$ & $-0.006^{* *}$ & $-0.003^{* *}$ \\
\hline & $(0.004)$ & $(0.002)$ & $(0.003)$ & $(0.002)$ \\
\hline \multirow{2}{*}{ BoardSize } & -0.017 & -0.015 & -0.001 & -0.004 \\
\hline & $(0.024)$ & $(0.018)$ & $(0.015)$ & $(0.012)$ \\
\hline \multirow[t]{2}{*}{ BoardIndep } & -0.002 & 0.003 & 0.001 & 0.002 \\
\hline & $(0.003)$ & $(0.002)$ & $(0.003)$ & $(0.002)$ \\
\hline \multirow[t]{2}{*}{ BoardAct } & $0.015^{* *}$ & $0.016^{* *}$ & 0.009 & 0.009 \\
\hline & $(0.007)$ & $(0.006)$ & $(0.008)$ & $(0.006)$ \\
\hline \multirow[t]{2}{*}{ CEOdual } & 0.074 & 0.050 & 0.004 & 0.027 \\
\hline & $(0.104)$ & $(0.068)$ & $(0.072)$ & $(0.045)$ \\
\hline \multirow[t]{2}{*}{ Constant } & $1.072^{* * *}$ & $1.144^{* * *}$ & $1.062^{* * *}$ & $1.457^{* * *}$ \\
\hline & $(0.407)$ & $(0.325)$ & $(0.406)$ & $(0.263)$ \\
\hline Observations & 169 & 174 & 205 & 212 \\
\hline $\mathrm{R} 2$ & 0.33 & 0.43 & 0.35 & 0.46 \\
\hline Year effects & Yes & Yes & Yes & Yes \\
\hline Industry effects & Yes & Yes & Yes & Yes \\
\hline
\end{tabular}

${ }^{* * *} p<0.01, * * p<0.05, * p<0.1$.

Regarding the control variables, unsurprisingly, the biggest determinant of the managerial reward is the firm's size measured through Sales. Leverage shows a negative sign in every regression of the baseline model, though it is only significant for the executive variable compensation. When the ownership is more concentrated, the compensation decreases for both CEO and executive compensation. Finally, an active board is positively associated to the $\mathrm{CEO}$ variable (coefficient of 0.015 ) and Total compensation (0.016).

Notably, we failed to find any significant association between the performance measure (ROE) and the compensation variables, as recommended by the governance code. 
4.3.2. Direct Association between High (or Low) CSR Performance Level and CEO/Executive Compensation

To test H2, we added to Model I a partitional dummy variable (CSR_d) that takes value 1 for those companies whose ESGCScore is above the median $(61,90)$ and value 0 for firms whose ESGCScore is below the median. The results shown in Table 7 (columns 1 and 2) display a negative and significant association of CSR investment effort (CSR_d) and the managerial compensation, both in variable and total measures. CEO compensation measures (columns 1 and 2) show a negative association with CSR investment effort (CSR_d), both for variable and total remuneration, though it only becomes significant for the latter. So, those companies included in the low-CSR effort group are more likely to link the CSR investment to the CEO total compensation, displaying a decrease of $7.2 \%$ when firms belong to the high-CSR group $\left(C S R \_d=1\right)$. Regarding the executive compensation results displayed in columns 3 and 4 , both variable and total compensation exhibit negative and significant coefficients. That is, those firms that belong to the group of low-CSR effort associate CSR to average variable compensation $16.3 \%$ more than those firms that belong to the high-CSR effort. In a similar way, the average total compensation increases by $11.2 \%$ in the case of firms included in the low-CSR effort group.

Table 7. Compensation results and CSR levels.

\begin{tabular}{|c|c|c|c|c|}
\hline & $\begin{array}{l}\text { CEO Variable } \\
\text { Compensation }\end{array}$ & $\begin{array}{c}\text { CEO Total } \\
\text { Compensation }\end{array}$ & $\begin{array}{c}\text { Executive Variable } \\
\text { Compensation }\end{array}$ & $\begin{array}{l}\text { Executive Total } \\
\text { Compensation }\end{array}$ \\
\hline VARIABLES & (1) & (2) & (3) & (4) \\
\hline ESGCScore & $\begin{array}{c}0.009 * * * \\
(3.128)\end{array}$ & $\begin{array}{l}0.006 * * \\
(2.176)\end{array}$ & $\begin{array}{l}0.012 * * * \\
(3.541)\end{array}$ & $\begin{array}{c}0.007^{* * *} \\
(4.107)\end{array}$ \\
\hline Sales & $\begin{array}{c}0.335^{* * *} \\
(4.440)\end{array}$ & $\begin{array}{c}0.306^{* * *} \\
(6.508)\end{array}$ & $\begin{array}{c}0.266^{* * *} \\
(3.390)\end{array}$ & $\begin{array}{c}0.244^{* * *} \\
(5.421)\end{array}$ \\
\hline ROE & $\begin{array}{c}0.001 \\
(0.771)\end{array}$ & $\begin{array}{c}0.000 \\
(0.954)\end{array}$ & $\begin{array}{l}-0.000 \\
(-0.001)\end{array}$ & $\begin{array}{c}0.000 \\
(0.570)\end{array}$ \\
\hline Leverage & $\begin{array}{c}-0.449 \\
(-1.513)\end{array}$ & $\begin{array}{c}-0.269 \\
(-1.226)\end{array}$ & $\begin{array}{l}-0.685^{* *} \\
(-2.476)\end{array}$ & $\begin{array}{l}-0.319^{* *} \\
(-2.095)\end{array}$ \\
\hline BoardOwn & $\begin{array}{c}-0.004 \\
(-1.023)\end{array}$ & $\begin{array}{c}-0.001 \\
(-0.394)\end{array}$ & $\begin{array}{l}-0.000 \\
(-0.106)\end{array}$ & $\begin{array}{l}-0.000 \\
(-0.067)\end{array}$ \\
\hline OwnerConc & $\begin{array}{l}-0.011^{* * *} \\
(-3.144)\end{array}$ & $\begin{array}{l}-0.006^{* * *} \\
(-2.622)\end{array}$ & $\begin{array}{l}-0.006^{* *} \\
(-2.109)\end{array}$ & $\begin{array}{l}-0.003^{*} \\
(-1.957)\end{array}$ \\
\hline BoardSize & $\begin{array}{l}-0.016 \\
(-0.721)\end{array}$ & $\begin{array}{l}-0.013 \\
(-0.753)\end{array}$ & $\begin{array}{c}0.002 \\
(0.119)\end{array}$ & $\begin{array}{c}-0.002 \\
(-0.220)\end{array}$ \\
\hline BoardIndep & $\begin{array}{l}-0.001 \\
(-0.455)\end{array}$ & $\begin{array}{c}0.003 \\
(1.450)\end{array}$ & $\begin{array}{c}0.001 \\
(0.441)\end{array}$ & $\begin{array}{c}0.002 \\
(1.094)\end{array}$ \\
\hline BoardAct & $\begin{array}{c}0.020 * * \\
(2.331)\end{array}$ & $\begin{array}{l}0.019 * * * \\
(2.770)\end{array}$ & $\begin{array}{c}0.011 \\
(1.216)\end{array}$ & $\begin{array}{l}0.012 * * \\
(2.088)\end{array}$ \\
\hline CEOdual & $\begin{array}{c}0.066 \\
(0.626)\end{array}$ & $\begin{array}{c}0.038 \\
(0.547)\end{array}$ & $\begin{array}{c}-0.000 \\
(-0.003)\end{array}$ & $\begin{array}{c}0.021 \\
(0.477)\end{array}$ \\
\hline CSR_d & $\begin{array}{l}-0.056 \\
(-1.230)\end{array}$ & $\begin{array}{l}-0.072 * \\
(-1.716)\end{array}$ & $\begin{array}{l}-0.163 * * * \\
(-2.730)\end{array}$ & $\begin{array}{c}-0.112 * * * \\
(-2.866)\end{array}$ \\
\hline Constant & $\begin{array}{l}0.989 * * \\
(2.276)\end{array}$ & $\begin{array}{l}1.048^{* * *} \\
(3.219)\end{array}$ & $\begin{array}{c}0.943 * * \\
(2.087)\end{array}$ & $\begin{array}{c}1.377^{* * *} \\
(5.072)\end{array}$ \\
\hline Observations & 169 & 174 & 205 & 212 \\
\hline $\mathrm{R} 2$ & 0.32 & 0.48 & 0.36 & 0.47 \\
\hline Year effects & Yes & Yes & Yes & Yes \\
\hline Industry effects & Yes & Yes & Yes & Yes \\
\hline
\end{tabular}

*** $p<0.01,{ }^{* *} p<0.05, * p<0.1$.

It is worth noting that, regarding the control variables, both Leverage and OwnerConc display the expected negative signs.

4.3.3. Direct Association between CSR Performance and the CEO/Executive Compensation Components

Following a previously tested methodology [23], in order to test $\mathrm{H} 3 \mathrm{a}$ and $\mathrm{H} 3 \mathrm{~b}$, in Model I we replaced the dependent variable with the two compensation components (in 
particular, the proportion of Cash and Equity). Table 8 displays the results of the association between the ESGCScore in year $t$ and the managerial compensation components. Columns 1 and 3 show that the coefficient of P_Equity is positive and significant. In this vein, the CEO and Executive percentage of equity-based remuneration display an increase of 0.328 and 0.299, respectively, when ESGScore increases 1 point. Columns 2 and 4 demonstrate that the cash component (P_Cash) is negative and significantly associated with the ESGCScore for both CEO and Executive positions. In this case, for each increment of 1 point in the ESGCScore, the proportion of the cash component in the remuneration structure is reduced in 0.328 for CEOs and 0.302 for Executives. These results confirm that our expectations from $\mathrm{H} 3 \mathrm{a}$ and $\mathrm{H} 3 \mathrm{a}$ about the CSR performance have an impact on the remuneration structure, incentivizing the equity-based part in detriment of the cash-based component.

Table 8. CSR performance effect on the compensation structure.

\begin{tabular}{|c|c|c|c|c|}
\hline & CEO & CEO & Executive & Executive \\
\hline & P_Equity & P_Cash & P_Equity & P_Cash \\
\hline VARIABLES & (1) & (2) & (3) & (4) \\
\hline ESGCScore & $\begin{array}{c}0.328^{* *} \\
(2.079)\end{array}$ & $\begin{array}{l}-0.328^{* *} \\
(-2.079)\end{array}$ & $\begin{array}{l}0.299 * * \\
(2.228)\end{array}$ & $\begin{array}{l}-0.302 * * \\
(-2.254)\end{array}$ \\
\hline Sales & $\begin{array}{c}0.377 \\
(0.127)\end{array}$ & $\begin{array}{c}-0.377 \\
(-0.127)\end{array}$ & $\begin{array}{c}-0.844 \\
(-0.264)\end{array}$ & $\begin{array}{c}0.702 \\
(0.221)\end{array}$ \\
\hline $\mathrm{ROE}$ & $\begin{array}{c}-0.061 \\
(-0.854)\end{array}$ & $\begin{array}{c}0.061 \\
(0.854)\end{array}$ & $\begin{array}{l}0.107^{*} \\
(1.692)\end{array}$ & $\begin{array}{l}-0.108 \text { * } \\
(-1.687)\end{array}$ \\
\hline Leverage & $\begin{array}{l}12.623 \\
(1.218)\end{array}$ & $\begin{array}{l}-12.623 \\
(-1.218)\end{array}$ & $\begin{array}{c}-6.421 \\
(-0.755)\end{array}$ & $\begin{array}{c}6.722 \\
(0.798)\end{array}$ \\
\hline BoardOwn & $\begin{array}{c}0.125 \\
(1.048)\end{array}$ & $\begin{array}{c}-0.125 \\
(-1.048)\end{array}$ & $\begin{array}{c}-0.033 \\
(-0.234)\end{array}$ & $\begin{array}{c}0.027 \\
(0.192)\end{array}$ \\
\hline OwnerConc & $\begin{array}{c}0.033 \\
(0.363)\end{array}$ & $\begin{array}{c}-0.033 \\
(-0.363)\end{array}$ & $\begin{array}{c}-0.080 \\
(-1.256)\end{array}$ & $\begin{array}{c}0.081 \\
(1.274)\end{array}$ \\
\hline BoardSize & $\begin{array}{c}-0.302 \\
(-0.328)\end{array}$ & $\begin{array}{c}0.302 \\
(0.328)\end{array}$ & $\begin{array}{c}0.029 \\
(0.047)\end{array}$ & $\begin{array}{c}-0.007 \\
(-0.011)\end{array}$ \\
\hline BoardIndep & $\begin{array}{c}-0.043 \\
(-0.356)\end{array}$ & $\begin{array}{c}0.043 \\
(0.356)\end{array}$ & $\begin{array}{c}0.015 \\
(0.140)\end{array}$ & $\begin{array}{c}-0.012 \\
(-0.110)\end{array}$ \\
\hline BoardAct & $\begin{array}{c}-0.256 \\
(-0.583)\end{array}$ & $\begin{array}{c}0.256 \\
(0.583)\end{array}$ & $\begin{array}{c}0.170 \\
(0.403)\end{array}$ & $\begin{array}{c}-0.183 \\
(-0.435)\end{array}$ \\
\hline CEOdual & $\begin{array}{c}-1.707 \\
(-0.394)\end{array}$ & $\begin{array}{c}1.707 \\
(0.394)\end{array}$ & $\begin{array}{c}-1.164 \\
(-0.346)\end{array}$ & $\begin{array}{c}1.178 \\
(0.350)\end{array}$ \\
\hline Constant & $\begin{array}{c}109.293^{* * *} \\
(6.689)\end{array}$ & $\begin{array}{c}-9.293 \\
(-0.569)\end{array}$ & $\begin{array}{c}1.150 \\
(0.107)\end{array}$ & $\begin{array}{c}99.320 * * * \\
(9.277)\end{array}$ \\
\hline Observations & 174 & 174 & 212 & 212 \\
\hline $\mathrm{R} 2$ & 0.04 & 0.04 & 0.07 & 0.07 \\
\hline Year effects & Yes & Yes & Yes & Yes \\
\hline Industry effects & Yes & Yes & Yes & Yes \\
\hline
\end{tabular}

\subsection{Robustness Tests}

\subsubsection{Heckman Two Stage Least Squares Approach to RSC}

The reverse causality between the firm's performance and CSR investments deserves further consideration. From the agency theory perspective, the board of directors can work as an information system for external stakeholders to monitor insider behavior. In this context, managerial compensation also provides the mechanism to shape managers' behavior. Therefore, CSR investments might be the consequence of certain managerial compensation schemes that aim to promote firms with a commitment to social responsibility. Similar causal relations are drawn from the managerial opportunity theory developed by Preston and O'Bannon [104]. According to this framework, when business performance declines, CEOs/Executives may attempt to improve their personal image in order to justify 
their disappointing results by, among other actions, participating in social programs. As a result, bad business performance (associated with lower managerial compensation) would cause higher CSR investments.

Regarding the managerial compensation structure, the inverse causality might also apply: If the compensation structure is appropriate, managers, in order to maximize their own wealth, will be more likely to invest in CSR [105].

To address those endogeneity concerns, we carried out the Heckman [106] approach, using 2SLS in order to control the endogeneity. We performed the simultaneous equation systems and the appropriate test of endogeneity, i.e., the Durbin [107] and $\mathrm{Wu}-$ Hausman $[108,109]$ tests, and they did not show any endogeneity problem. Accordingly, the application of the OLS technique seems to be appropriate, since it offers more consistent and less biased coefficients. Notably, the results are consistent with those displayed in the prior analyses.

\subsubsection{Additional Grouping of CSR Levels}

To corroborate the impact of the CSR levels of investment on managerial compensation, we split the two subsamples (High CSR and Low CSR) into two additional subsamples, following the same median criteria. Hence, we ran the regression on the four subsamples (High CSR, Medium-high CSR, Medium-low CSR, Low CSR), and the untabulated results show the same association, thus confirming the conclusions drawn from the baseline regressions.

\subsubsection{Lagged RSC Variable}

Following the methodology applied in Lopez-Iturriaga et al. [33], we lagged the ESGCScore one year, because it is plausible that managerial compensation is referred to prior performance targets. Again, the undisclosed results lead to the conclusions of the main results.

\section{Discussion of the Results}

To date, several theories aim to explain the relationship between CSR investments and managerial compensation. Since prior empirical evidence provides contradictory results, whether and how managerial compensation is tied to CSR goals is a research issue that needs to be empirically solved.

We report that CEO and Executive (total and variable) compensations are positively associated with CSR performance (thus confirming H1). This result is supportive of the agency theory premises because it postulates that the design of the managerial compensation scheme is a good tool to better align the interests of shareholders and managers. Therefore, if the company is really committed to improving their CSR performance, the optimal contract should link the managerial compensation to CSR levels. On the contrary, we failed to corroborate the predictions of the stakeholder theory, that is, the more socially responsible the firm, the lower managerial compensation it will offer.

However, the outcomes of additional tests suggest that this relationship is positive only for the groups of firms with lower CSR investments (we confirm H2a) and lacks significance for the set of firms with high (abnormal) CSR level (we failed to prove H2b). Regarding the managerial compensation structure, CSR is positively associated with equity-based compensation and negatively linked to cash-based compensation. These results might be better explained by the institutional theory developed by DiMaggio and Powell [64]: The institutional isomorphism might provide a plausible explanation for firms with lower CSR parameters trying to imitate more socially responsible firms and designing managerial compensation schemes according to the CSR goals. Thus, the coefficient displayed by our variable of interest is positive for the lowest socially responsible firms, in the same vein of Mizruchi and Fein [65] or Fernando and Lawrence [66].

Regarding the managerial compensation component, the incentive to achieve CSR goals seems to be connected with shares-based compensation, that is commonly considered as rewarding in the long term. Thus, our results are supportive of CSR investments 
associated to long-term managerial incentives, although another plausible explanation is that, when managers believe that CSR investment is an attractive alternative to increase the firm's value in the long term, they are more willing to accept long-term rewarding components such as equity shares. Similar conclusions were reached by Milbourn [67], who reports a positive relation between CEO stock-based compensation and CSR reputation, or McGuire et al. [21], that revealed that both CEO salary and long-term compensation was positively related to CSR performance.

Regarding the control variables, it is worth noting that leverage displays a negative association with the managerial compensation, thus confirming the monitoring role of banks as providers of external funds in Spain. The negative sign exhibited by the ownership concentration variable also confirms that institutional investors play a crucial role in shaping the managerial compensation, as Lopez-Iturriaga et al. [33] conclude. This incentive is especially relevant because, according to our results, the firm's performance is not a main driver of the managerial compensation (consistent with Forcadell and Aracil [52]).

\section{Conclusions and Limitations of the Study}

The aim of this paper is to shed some light on to the association between CSR and managerial performance.

Since the publication of the Sustainability Law in 2011, Spain has undertaken several initiatives for the development of, and business commitment to, CSR. Apparently, it seems that they are rather effective, since our data indicates that the mean score of the ESG combined Score (index estimated on firm's CSR disclosures) in Spain is 5900 above the European average of 51.05 reported by Iamandi et al. [110].

Our results confirm that the managerial compensation levels, both in terms of variable and total compensation, are positively associated with CSR performance [111], after controlling for financial and corporate governance attributes, such as ownership structure or board characteristics.

We also report that the firms with lower socially responsible levels are the ones that are linking CSR goals and managerial compensation in a significant and positive way. Therefore, in accordance with the agency theory, the companies might design optimal contracts that seek to achieve higher CSR investments.

Additional findings demonstrate that the CSR performance is positively connected with the equity-based compensation and negatively connected with the proportion of cash-based compensation. However, the high proportion of cash-based compensation is far from the desirable goals promoted by the Governance Codes.

Among the limitations of this research, we are aware that the measure of CSR investments through the ESGCScore presents some flaws: in the first place, despite being a comprehensive index that includes more than 40 items, there might be relevant issues that are not considered. In the second place, the index is based on the CSR practices reported by the firm. However, the CSR reporting has been criticized for its lack of relevance and credibility [112]. Therefore, alternate measures of CSR might provide more robust results.

We also reckon that, as in any archival research, our conclusions are constrained by the data availability and, therefore, there might be a survivorship bias. In addition, only the biggest companies are supplying the information collected by the ESGCScore, and therefore this study would need to be complemented with data related with smaller companies to fully understand a firm's behavior on RSC grounds.

Finally, although we tried to build a comprehensive model, some relevant omitted variables might also explain the managerial compensation.

Author Contributions: Conceptualization, F.B., C.D.F. and R.P.; methodology, F.B., C.D.F. and R.P.; software, F.B., C.D.F. and R.P.; validation, F.B., C.D.F. and R.P.; formal analysis, F.B., C.D.F. and R.P.; investigation, F.B., C.D.F. and R.P.; resources, F.B., C.D.F. and R.P.; data curation, F.B., C.D.F. and R.P.; writing-original draft preparation, F.B., C.D.F. and R.P.; writing-review and editing, F.B., C.D.F. and R.P.; visualization, F.B., C.D.F. and R.P.; supervision, F.B., C.D.F. and R.P.; project administration, 
F.B., C.D.F. and R.P.; funding acquisition, F.B., C.D.F. and R.P. All authors have read and agreed to the published version of the manuscript.

Funding: This research received no external funding.

Data Availability Statement: The data of this study has been hand-collected from CNMV, both annual reports of individual companies and the compensation reports.

Conflicts of Interest: The authors declare no conflict of interest.

\section{Appendix A}

Table A1. Variables of the Tested Models.

\begin{tabular}{|c|c|c|}
\hline Label & Definition & Expected Sign \\
\hline $\begin{array}{c}\text { CEO } \\
\text { Total_Pay }\end{array}$ & $\begin{array}{l}\text { Sum of all variable and non-variable remuneration received in cash, } \\
\text { non-cash, or shares perceived by the highest-ranked executive } \\
\text { member of the board of directors, transformed into nat log values. }\end{array}$ & \\
\hline $\begin{array}{c}\text { CEO } \\
\text { Total_Var }\end{array}$ & $\begin{array}{c}\text { Sum of cash and shares linked to performance and perceived by the } \\
\text { highest-ranked executive member of the board of directors, } \\
\text { transformed into nat log values. }\end{array}$ & \\
\hline $\begin{array}{l}\text { Executives } \\
\text { Total_Pay }\end{array}$ & $\begin{array}{l}\text { Average sum of all variable and non-variable remuneration } \\
\text { received in cash, non-cash, or shares perceived by the board } \\
\text { members with executive functions, transformed into nat log values. }\end{array}$ & \\
\hline $\begin{array}{l}\text { Executives } \\
\text { Total_Var }\end{array}$ & $\begin{array}{l}\text { Average sum of cash and shares linked to performance and } \\
\text { perceived by the board members with executive functions, } \\
\text { transformed into nat log values. }\end{array}$ & \\
\hline P_Cash & $\begin{array}{l}\text { Proportion of cash-based compensation (salary and bonus) to } \\
\text { total compensation }\end{array}$ & \\
\hline P_Equity & Proportion of equity-based compensation & \\
\hline BoardSize & Total members of the Board of Directors & + \\
\hline BoardAct & Number of Board of Directors meetings per year & - \\
\hline BoardIndep & $\begin{array}{l}\% \text { of non-executive board members } \\
\text { Stock owned by the largest-block shareholders. Following the }\end{array}$ & - \\
\hline OwnerConc & $\begin{array}{l}\text { CNMV criteria, a significant shareholder exerts influence in the } \\
\text { shareholders' meetings when the participation rises to, at least, } 3 \% \\
\text { of the share capital. }\end{array}$ & - \\
\hline CEOdual & $\begin{array}{l}\text { Dichotomic variable that takes the value } 1 \text { if the C.E.O. and the } \\
\text { Chairman of the Board are the same person, and } 0 \text { otherwise }\end{array}$ & + \\
\hline BoardOwn & $\%$ of stock controlled by the board & - \\
\hline Sales & Natural Logarithm of company's sales. & + \\
\hline ROE & Return on Equity (Net income divided by total equity) & + \\
\hline Leverage & $\begin{array}{l}\text { Total debt (current and long term)/total assets } \\
\text { Index designed to measure the CSR performance on ESG }\end{array}$ & - \\
\hline ESGCScore & $\begin{array}{l}\text { (Environmental, Social and Governance) areas. It is structured } \\
\text { according to } 178 \text { indicators from more than } 400 \text { company level } \\
\text { ESG measures. }\end{array}$ & $+1-$ \\
\hline
\end{tabular}

\section{References}

1. De Andrés, P.; Reig, R.; Vallelado, E. European banks' executive remuneration under the new European Union regulation. J. Econ. Policy Reform 2018, 22, 208-225. [CrossRef]

2. Merino, E.; Manzaneque-Lizano, M.; Sanchez-Araque, J. Sustainability and Corporate Governance: Transparency and Excessive Directors' Remuneration in Listed Companies during the Global Financial Crisis. Sustainability 2019, 12, 158. [CrossRef]

3. Brandes, P.; Goranova, M.; Hall, S. Navigating Shareholder Influence: Compensation Plans and the Shareholder Approval Process. Acad. Manag. Perspect. 2008, 22, 41-57. [CrossRef]

4. Mishel, L.; Wolfe, J. CEO Compensation Has Grown 940\% Since 1978; Economic Policy Institute: Washington, DC, USA, 2019; Volume 14.

5. Cuomo, F.; Mallin, C.; Zattoni, A. Corporate Governance Codes: A Review and Research Agenda. Corp. Gov. Int. Rev. 2016, 24, 222-241. [CrossRef]

6. OECD. G20/OECD Principles of Corporate Governance; OECD Publishing: Paris, France, 2015. [CrossRef] 
7. European Parliament. Directives 2009/385/CE, 2013/36/CE, 2014/95/CE 2017/828/CE. Available online: https:/ /eur-lex. europa.eu/legal-content/ES/TXT/?uri=CELEX\%3A32017L0828 (accessed on 29 June 2021).

8. Holmstrom, B. Moral Hazard and Observability. Bell J. Econ. 1979, 10, 74. [CrossRef]

9. Jensen, M.C.; Murphy, K.J. Performance Pay and Top-Management Incentives. J. Political Econ. 1990, 98, 225-264. [CrossRef]

10. Jensen, M.C.; Meckling, W.H. Theory of the firm: Managerial behavior, agency costs and ownership structure. J. Financ. Econ. 1976, 3, 305-360. [CrossRef]

11. Murphy, K.J. Explaining Executive Compensation: Managerial Power versus the Perceived Cost of Stock Options. Univ. Chic. Law Rev. 2002, 69, 847. [CrossRef]

12. Murphy, K.J.; Zábojník, J. CEO Pay and Appointments: A Market-Based Explanation for Recent Trends. Am. Econ. Rev. 2004, 94, 192-196. [CrossRef]

13. French Assemblée Nationale. Duty of Vigilance Law in France; French Assemblée Nationale: Paris, France, 2017.

14. Financial Reporting Council. UK Companies Act. 2006. Available online: https://www.frc.org.uk/getattachment/8238c251-5cfe43b7-abc0-4318ccbdc0fd/Combined-Code-2006-(Oct-version).pdf (accessed on 29 June 2021).

15. Congress of the People's Republic of China. Companies Act. 2006. Available online: https://www.ilo.org/dyn/natlex/docs/ ELECTRONIC/92643/108008/F-186401967/CHN92643\%20Eng.pdf (accessed on 29 June 2021).

16. Parliament of India. Companies Act: Mandatory CSR Contributions. 2013. Available online: https://www.mca.gov.in/Ministry/ pdf/InvitationOfPublicCommentsHLC_18012019.pdf (accessed on 29 June 2021).

17. Investor Responsibility Research Center \& the Sustainable Investments Institute Join Report. 2013. Available online: https: / / www.weinberg.udel.edu/irrci/ (accessed on 29 June 2021).

18. Tosi, H.L.; Werner, S.; Katz, J.P.; Gomez-Mejia, L.R. How Much Does Performance Matter? A Meta-Analysis of CEO Pay Studies. J. Manag. 2000, 26, 301-339. [CrossRef]

19. Blanes, F.; de Fuentes, C.; Porcuna, R. Executive remuneration determinants: New evidence from meta-analysis. Econ. Res. Ekon. IstražIvanja 2020, 33, 2844-2866. [CrossRef]

20. Elsilä, A.; Kallunki, J.-P.; Nilsson, H.; Sahlström, P. CEO Personal Wealth, Equity Incentives and Firm Performance. Corp. Gov. Int. Rev. 2012, 21, 26-41. [CrossRef]

21. McGuire, J.; Dow, S.; Argheyd, K. CEO Incentives and Corporate Social Performance. J. Bus. Ethics 2003, 45, 341-359. [CrossRef]

22. Cai, Y.; Jo, H.; Pan, C. Vice or Virtue? The Impact of Corporate Social Responsibility on Executive Compensation. J. Bus. Ethics 2011, 104, 159-173. [CrossRef]

23. Karim, K.; Lee, E.; Suh, S. Corporate social responsibility and CEO compensation structure. Adv. Account. 2018, 40, 27-41. [CrossRef]

24. Jian, M.; Lee, K.-W. CEO compensation and corporate social responsibility. J. Multinatl. Financ. Manag. 2015, 29, 46-65. [CrossRef]

25. Ikram, A.; Li, Z.; MacDonald, T. CEO Pay Sensitivity (Delta and Vega) and Corporate Social Responsibility. Sustainability 2020, 12, 7941. [CrossRef]

26. La Porta, R.; Lopez-De-Silanes, F.; Shleifer, A.; Vishny, R.W. Law and Finance. J. Political Econ. 1998, 106, 1113-1155. [CrossRef]

27. Leuz, C.; Nanda, D.; Wysocki, P.D. Earnings management and investor protection: An international comparison. J. Financ. Econ. 2003, 69, 505-527. [CrossRef]

28. Millar, C.C.; Eldomiaty, T.I.; Choi, C.J.; Hilton, B. Corporate Governance and Institutional Transparency in Emerging Markets. J. Bus. Ethics 2005, 59, 163-174. [CrossRef]

29. Claessens, S.; Djankov, S.; Lang, L.H. The separation of ownership and control in East Asian Corporations. J. Financ. Econ. 2000, 58, 81-112. [CrossRef]

30. Claessens, S.; Yurtoglu, B.B. Corporate governance in emerging markets: A survey. Emerg. Mark. Rev. 2013, 15, 1-33. [CrossRef]

31. García-Meca, E.; Sánchez-Ballesta, J.P. Corporate Governance and Earnings Management: A Meta-Analysis. Corp. Gov. Int. Rev. 2009, 17, 594-610. [CrossRef]

32. Pucheta-Martínez, M.C.; García-Meca, E. Institutional Investors on Boards and Audit Committees and Their Effects on Financial Reporting Quality. Corp. Gov. Int. Rev. 2014, 22, 347-363. [CrossRef]

33. López-Iturriaga, F.; García-Meca, E.; Tejerina-Gaite, F. Institutional directors and board compensation: Spanish evidence. BRQ Bus. Res. Q. 2015, 18, 161-173. [CrossRef]

34. Congress of Spain. Law 2/2011, on Spain's Sustainable Economy. 2011. Available online: https:/ / www.eesc.europa.eu/resources / docs/the-spanish-law-on-social-economy.pdf (accessed on 29 June 2021).

35. Congress of Spain. Law 31/2014, of December 3, Which Modifies the Capital Companies Act to Improve Corporate Governance. 2014. Available online: https://ec.europa.eu/energy/sites/default/files/documents/ec_courtesy_translation_es_necp.pdf (accessed on 29 June 2021).

36. Congress of Spain. Law 11/2018 for the Applicable Rules on the Disclosure of Non-Financ, and Diversity Information in Spain. 2018. Available online: https:/ / www.ey.com/en_gl/tax-alerts/spain-approves-rules-on-tax-information-to-be-included-innon-financial-reporting (accessed on 29 June 2021).

37. CNMV. Code of Good Governance of Spanish Listed Companies. 2015. Available online: https://www.cnmv.es/DocPortal/ Publicaciones/CodigoGov/Good_Governanceen.pdf (accessed on 29 June 2021).

38. Jo, H.; Harjoto, M.A. Corporate Governance and Firm Value: The Impact of Corporate Social Responsibility. J. Bus. Ethics 2011, 103, 351-383. [CrossRef] 
39. Core, J.E.; Holthausen, R.W.; Larcker, D.F. Corporate governance, chief executive officer compensation, and firm performance. J. Financ. Econ. 1999, 51, 371-406. [CrossRef]

40. Bebchuk, L.A.; Fried, J.M. Executive Compensation as an Agency Problem. J. Econ. Perspect. 2003, 17, 71-92. [CrossRef]

41. Van Essen, M.; Otten, J.; Carberry, E.J. Assessing Managerial Power Theory: A meta-analytic approach to understanding the determinants of CEO compensation. J. Manag. 2012, 41, 164-202. [CrossRef]

42. Kim, K.A.; Kitsabunnarat-Chatjuthamard, P.; Nofsinger, J.R. Large shareholders, board independence, and minority shareholder rights: Evidence from Europe. J. Corp. Financ. 2007, 13, 859-880. [CrossRef]

43. Murphy, K.J. Executive compensation: Where we are, and how we got there. In Handbook of the Economics of Finance; Elsevier: Amsterdam, The Netherlands, 2013; Volume 2, pp. 211-356.

44. Chalevas, C.G. The Effect of the Mandatory Adoption of Corporate Governance Mechanisms on Executive Compensation. Int. J. Account. 2011, 46, 138-174. [CrossRef]

45. Edmans, A. Performance Based Pay for Executives Still Works. 2016. Available online: https://hbr.org/2016/02/performancebased-pay-for-executives-still-works (accessed on 29 June 2021).

46. Chen, H.; Jeter, D.; Yang, Y.-W. Pay-performance sensitivity before and after SOX. J. Account. Public Policy 2015, 34, 52-73. [CrossRef]

47. Financial Reporting Council. UK Companies Act. 2010. Available online: https://www.frc.org.uk/getattachment/31631a7a-bc5 c-4e7b-bc3a-972b7f17d5e2/UK-Corp-Gov-Code-June-2010.pdf (accessed on 29 June 2021).

48. Bebchuk, L.A.; Fried, J.M. Pay without Performance; Harvard University Press: Cambridge, MA, USA, 2004.

49. Banghøj, J.; Gabrielsen, G.; Petersen, C.; Plenborg, T. Determinants of executive compensation in privately held firms. Account. Financ. 2010, 50, 481-510. [CrossRef]

50. Congress of Spain. Law 9/2020 that Modifies the Law 2005 about Carbon Emissions. 2020. Available online: https: / / ec.europa. eu/energy/sites/default/files/documents/ec_courtesy_translation_es_necp.pdf (accessed on 29 June 2021).

51. Cheng, B.; Ioannou, I.; Serafeim, G. Corporate social responsibility and access to finance. Strat. Manag. J. 2014, 35, 1-23. [CrossRef]

52. Forcadell, F.J.; Aracil, E. European Banks' Reputation for Corporate Social Responsibility. Corp. Soc. Responsib. Environ. Manag. 2017, 24, 1-14. [CrossRef]

53. Freeman, R.E. Strategic Management: A Stakeholder Approach; Pitman Publishing: Boston, MA, USA, 1984.

54. Freeman, R.E.; Velamuri, S.R. A New Approach to CSR: Company Stakeholder Responsibility. In Corporate Social Responsibility; Palgrave Macmillan: London, UK, 2006; pp. 9-23.

55. Wood, D.J. Social Issues in Management: Theory and Research in Corporate Social Performance. J. Manag. 1991, 17, $383-406$. [CrossRef]

56. Greening, D.W.; Turban, D.B. Corporate Social Performance As a Competitive Advantage in Attracting a Quality Workforce. Bus. Soc. 2000, 39, 254-280. [CrossRef]

57. Sen, S.; Bhattacharya, C. Does Doing Good Always Lead to Doing Better? Consumer Reactions to Corporate Social Responsibility. J. Mark. Res. 2001, 38, 225-243. [CrossRef]

58. Allouche, J.; Laroche, P. A meta-analytical investigation of the relationship between corporate social and financial performance. Rev. Gest. Ressour. Hum. 2005, 57, 18.

59. Cronqvist, H.; Heyman, F.; Nilsson, M.; Svaleryd, H.; Vlachos, J. Do Entrenched Managers Pay Their Workers More? J. Financ. 2009, 64, 309-339. [CrossRef]

60. Pagano, M.; Volpin, P.F. Managers, Workers, and Corporate Control. J. Financ. 2005, 60, 841-868. [CrossRef]

61. Rashid, A.; Shams, S.; Bose, S.; Khan, H. CEO power and corporate social responsibility (CSR) disclosure: Does stakeholder influence matter? Manag. Audit. J. 2020. [CrossRef]

62. Potts, M. CEO compensation and virtue ethics. In The Ethics of Executive Compensation; Kolb, R.W., Ed.; Blackwell Publishing Ltd.: Oxford, UK, 2006.

63. Russo, M.V.; Harrison, N.S. Organizational Design and Environmental Performance: Clues from the Electronics Industry. Acad. Manag. J. 2005, 48, 582-593. [CrossRef]

64. DiMaggio, P.J.; Powell, W.W. The Iron Cage Revisited: Institutional Isomorphism and Collective Rationality in Organizational Fields. Am. Sociol. Rev. 1983, 48, 147. [CrossRef]

65. Mizruchi, M.S.; Fein, L.C. The Social Construction of Organizational Knowledge: A Study of the Uses of Coercive, Mimetic, and Normative Isomorphism. Adm. Sci. Q. 1999, 44, 653. [CrossRef]

66. Fernando, S.; Lawrence, S. A theoretical framework for CSR practices: Integrating legitimacy theory, stakeholder theory and institutional theory. J. Theor. Account. Res. 2014, 10, 149-178.

67. Milbourn, T.T. CEO reputation and stock-based compensation. J. Financ. Econ. 2003, 68, 233-262. [CrossRef]

68. Berrone, P.; Gomez-Mejia, L.R. Environmental Performance and Executive Compensation: An Integrated Agency-Institutional Perspective. Acad. Manag. J. 2009, 52, 103-126. [CrossRef]

69. Ernst and Young. Is Your Non-Financial Performance Revealing the True Value of Your Business to Investors? Tomorrow's Investment Rules 2017. Available online: https://www.ey.com/en_gl/assurance/is-your-nonfinancial-performance-revealingthe-true-value-of-your-business (accessed on 15 April 2021).

70. Surroca, J.; Tribó, J.A. Managerial Entrenchment and Corporate Social Performance. J. Bus. Financ. Account. 2008, 35, 748-789. [CrossRef] 
71. Barnea, A.; Rubin, A. Corporate Social Responsibility as a Conflict between Shareholders. J. Bus. Ethics 2010, 97, 71-86. [CrossRef]

72. Javeed, S.A.; Lefen, L. An Analysis of Corporate Social Responsibility and Firm Performance with Moderating Effects of CEO Power and Ownership Structure: A Case Study of the Manufacturing Sector of Pakistan. Sustainability 2019, 11, 248. [CrossRef]

73. Peng, C. The role of business strategy and CEO compensation structure in driving corporate social responsibility: Linkage towards a sustainable development perspective. Corp. Soc. Responsib. Environ. Manag. 2020, 27, 1028-1039. [CrossRef]

74. Dai, Y.; Rau, P.R.; Stouraitis, A.; Tan, W. An ill wind? Terrorist attacks and CEO compensation. J. Financ. Econ. 2020, 135, 379-398. [CrossRef]

75. Deckop, J.R.; Merriman, K.K.; Gupta, S. The Effects of CEO Pay Structure on Corporate Social Performance. J. Manag. 2006, 32, 329-342. [CrossRef]

76. Jouber, H. How does CEO pay slice influence corporate social responsibility? U.S.-Canadian versus Spanish-French listed firms. Corp. Soc. Responsib. Environ. Manag. 2019, 26, 502-517. [CrossRef]

77. Russo, M.V.; Fouts, P.A. A resource-based perspective on corporate environmental performance and profitability. Acad. Manag. J. 1997, 40, 534-559.

78. Chan, M.C.; Watson, J.; Woodliff, D. Corporate Governance Quality and CSR Disclosures. J. Bus. Ethics 2014, 125, 59-73. [CrossRef]

79. Garcia-Torea, N.; Fernandez-Feijoo, B.; de la Cuesta, M. The influence of ownership structure on the transparency of CSR reporting: Empirical evidence from Spain. Span. J. Financ. Account. 2017, 46, 249-271. [CrossRef]

80. Odriozola, M.D.; Baraibar-Diez, E. Is Corporate Reputation Associated with Quality of CSR Reporting? Evidence from Spain. Corp. Soc. Responsib. Environ. Manag. 2017, 24, 121-132. [CrossRef]

81. Greene, W.H. Fixed Effects Vector Decomposition: A Magical Solution to the Problemof Time-invariant Variables in Fixed Effects Models? Political Anal. 2012, 19, 135-146. [CrossRef]

82. Pucheta-Martínez, M.C.; Gallego-Álvarez, I. Do board characteristics drive firm performance? An international perspective. Rev. Manag. Sci. 2020, 14, 1251-1297. [CrossRef]

83. Buck, T.; Bruce, A.; Main, B.G.; Udueni, H. Long term incentive plans, executive pay and UK company performance. J. Manag. Stud. 2003, 40. [CrossRef]

84. Buck, T.; Liu, X.; Skovoroda, R. Top executive pay and firm performance in China. J. Int. Bus. Stud. 2008, 39, 833-850. [CrossRef]

85. Croci, E.; Gonenc, H.; Ozkan, N. CEO compensation, family control, and institutional investors in Continental Europe. J. Bank. Financ. 2012, 36, 3318-3335. [CrossRef]

86. Bertrand, M.; Mullainathan, S. Are CEOs Rewarded for Luck? The Ones without Principals Are. Q. J. Econ. 2001, 116, 901-932. [CrossRef]

87. Zhou, X. Executive compensation and managerial incentives: A comparison between Canada and the United States. J. Corp. Financ. 1999, 5, 277-301. [CrossRef]

88. Randøy, T.; Nielsen, J. Company Performance, Corporate Governance, and CEO Compensation in Norway and Sweden. J. Manag. Gov. 2002, 6, 57-81. [CrossRef]

89. Elston, J.A.; Goldberg, L.G. Executive compensation and agency costs in Germany. J. Bank. Financ. 2003, 27, 1391-1410. [CrossRef]

90. Jensen, M.C. Agency costs of free cash flow, corporate finance, and takeovers. Corp. Bankruptcy 1996, 76, 11-16. [CrossRef]

91. Basu, S.; Hwang, L.-S.; Mitsudome, T.; Weintrop, J. Corporate governance, top executive compensation and firm performance in Japan. Pac. Basin Financ. J. 2007, 15, 56-79. [CrossRef]

92. Chung, H.; Judge, W.Q.; Li, Y.-H. Voluntary disclosure, excess executive compensation, and firm value. J. Corp. Financ. 2015, 32, 64-90. [CrossRef]

93. Larmou, S.; Vafeas, N. The relation between board size and firm performance in firms with a history of poor operating performance. J. Manag. Gov. 2009, 14, 61-85. [CrossRef]

94. Chhaochharia, V.; Grinstein, Y. CEO Compensation and Board Structure. J. Financ. 2009, 64, 231-261. [CrossRef]

95. Ozkan, N. CEO Compensation and Firm Performance: An Empirical Investigation of UK Panel Data. Eur. Financ. Manag. 2009, 17, 260-285. [CrossRef]

96. Vafeas, N. Board meeting frequency and firm performance. J. Financ. Econ. 1999, 53, 113-142. [CrossRef]

97. Lin, Y.-F.; Yeh, Y.M.C.; Yang, F.-M. Supervisory quality of board and firm performance: A perspective of board meeting attendance. Total Qual. Manag. Bus. Excel. 2013, 25, 264-279. [CrossRef]

98. Luo, Y. CEO power, ownership structure and pay performance in Chinese banking. J. Econ. Bus. 2015, 82, 3-16. [CrossRef]

99. Conyon, M.J.; He, L. Executive compensation and corporate governance in China. J. Corp. Financ. 2011, 17, 1158-1175. [CrossRef]

100. Merino, E.; Manzaneque, M.; Banegas, R. (Eds.) Control of directors' compensation inSpanish companies: Corporate governance and firm performance. In Performance Measurement and Management Control: Global Issues; Emerald Group Publishing Limited: Bingley, UK, 2016; pp. 391-425.

101. Boyd, B. Board control and ceo compensation. Strat. Manag. J. 1994, 15, 335-344. [CrossRef]

102. Hair, J.F., Jr.; Anderson, R.E.; Tatham, R.L.; Black, W.C. Multivariate Data Analysis, 3rd ed.; Macmillan: New York, NY, USA, 1995.

103. Wooldridge, J.M. Introductory Econometrics: A Modern Approach; Cengage learning: Mason, OH, USA, 2015.

104. Preston, L.E.; O’bannon, D.P. The corporate social-financial performance relationship: A typology and analysis. Bus. Soc. 1997, 36, 419-429. [CrossRef]

105. Borlea, S.N.; Achim, M.V.; Mare, C. Board characteristics and firm performances in emerging economies. Lessons from Romania. Econ. Res. Ekon. Istraživanja 2017, 30, 55-75. [CrossRef] 
106. Heckman, J.J. Statistical Models for Discrete Panel Data; Department of Economics and Graduate School of Business, University of Chicago: Chicago, IL, USA, 1979.

107. Durbin, J. Errors in Variables. Rev. Int. Stat. Inst. 1954, 22, 23-32. [CrossRef]

108. Wu, D.-M. Alternative Tests of Independence between Stochastic Regressors and Disturbances. Econom. J. Econom. Soc. 1973, 41, 733. [CrossRef]

109. Hausman, J.A. Specification Tests in Econometrics. Econometrica 1978, 46, 1251. [CrossRef]

110. Iamandi, I.-E.; Constantin, L.-G.; Munteanu, S.M.; Cernat-Gruici, B. Mapping the ESG Behavior of European Companies. A Holistic Kohonen Approach. Sustainability 2019, 11, 3276. [CrossRef]

111. Hong, B.; Li, Z.; Minor, D. Corporate Governance and Executive Compensation for Corporate Social Responsibility. J. Bus. Ethics 2016, 136, 199-213. [CrossRef]

112. Husillos, J.; González, C.L.; Alvarez-Gil, M.J. The emergence of triple bottom line reporting in Spain. Span. J. Financ. Account. 2011, 40, 195-219. [CrossRef] 